\title{
Mobilitas Permanen: Backpacking sebagai Karier Subkultural Kaum Muda Nomad Kontemporer
}

\author{
Sidiq Hari Madya \\ Departemen Sosiologi, FISIPOL UGM \\ sidiqharim@gmail.com
}

\begin{abstract}
Backpacking seems to become a cultural symbol of contemporary youth nomadism. Backpackers arrange their own trip with more flexible itinerary and construction of identity that often opposes tourists' identity. The characteristics of their travel makes backpacker capable of forming their own travel subculture. By interviewing 15 Indonesian backpackers and intensively observing their travel journeys posted online in backpacker forum and their social media pages, this study explores the backpacking activity as a potential for subcultural career among today's traveling youth. Three types of backpacker subcultural career are identified under the headline of open trip, endorsed trip and business trip. This finding contributes to enrich backpacker discussion in the frame of traveling as a work activity.
\end{abstract}

KEYWORDS Backpaking | Subculture Career | Travelling

\section{PENDAHULUAN}

Backpacker merupakan salah satu simbol nomadisme kaum muda kontemporer (Richards 2015). Backpacker sering disebut sebagai traveler atau pejalan mandiri (Richards and Wilson 2004). Tentu saja, istilah mandiri tidak mengacu pada praktik perjalanan yang tidak bergantung pada siapapun. Backpacker, sama seperti traveler lainnya, selalu bergantung pada sistem travel, seperti transportasi, akomodasi, destinasi dan sebagainya yang memungkinkan dirinya untuk melakukan mobilitas. Mandiri dalam konteks backpacking lebih menekankan pada independensi traveler dalam mengatur dan mengontrol perjalannya, baik sebelum, saat, maupun setelah traveling. Backpacker cenderung menjaga jarak dari intervensi dan kontrol pihak lain dalam aktivitas travelingnya, seperti misalnya peran agen travel. Independensi dari agen travel membentuk komposisi yang membedakan backpacking dengan traveling berkelompok seperti yang tampak pada fenomena mass tourism (Welk 2004).

Namun apakah backpacker merupakan traveler yang anti-agen travel atau anti-turis masih menjadi perdebatan. Cohen (1972) membedakan bentuk perjalanan dalam konteks pariwisata ke dalam dua jenis, yaitu institutionalized dan non institutionalized. Turis yang datang ke lokasi wisata sebagai bagian dari mass tourism dengan itinerari yang diatur oleh agen atau biro travel dan mengikuti kemana pemandu wisata mengarahkan dikategorikan ke dalam institutionalized tourism. Sedangkan turis yang perjalanannya tidak diorganisir oleh pihak lain seperti biro travel digolongkan sebagai bentuk non institutionalized tourism. Backpacker yang mengorganisir sendiri perjalanannya, termasuk untuk tujuan wisata merupakan fenomena non institutionalized tourism.

Istilah backpacking berasal dari Barat (Bahasa Inggris). Pada mulanya istilah ini diambil dari kata backpack-sebutan untuk barang fisik berupa tas yang digendong di punggung. Namun dalam konteks traveling, backpacking tidak lagi mengacu pada emblem fisik jenis tas, melainkan pada emblem kultural yang melekat pada praktik perjalanan dengan karak- 
teristik yang khas (Richards and Wilson 2004). Definisi istilah yang merujuk pada emblem kultural ini menunjukkan bahwa backpacking tidak lagi ada hubungannya dengan perjalanan yang dilakukan dengan menggendong tas backpack. Backpacking adalah tentang pengorganisasian, praktik dan pengalaman perjalanan traveler secara independen.

Sørensen (2003) medefinisikan backpacker sebagai tipe turis yang mengorganisir sendiri perjalanannya dengan tujuan jalan-jalan atau berwisata yang biasanya tidak hanya mengunjungi satu destinasi saja. Backpacker menurut Sørensen (2003) juga mengorganisir perjalanan dengan menyusun itinerari yang fleksible dengan kemungkinan untuk memperpanjang perjalannnya tanpa direncanakan sebelumnya. Kemandirian dan fleksibilitas yang membentuk karakteristik perjalanan backpacker membedakan backpacker dengan turis dalam beberapa hal, salah satunya kebebasan mobilitas, meskipun backpacker masih digolongkan sebagai tipe turis.

Mendefinisikan backpacker dapat dimulai dari mengidentifikasi karakteristik sosial dan ekonomi backpacker serta kapan orang-orang melakukan backpacking. Beberapa studi menunjukkan bahwa mereka yang backpacking kebanyakan adalah anak-anak muda (Loker-Murphy and Pearce 1995; Sørensen 2003; Noy 2004; Richards 2015). Backpacking sering kali dilakukan sebagai bagian dari rite of passage dimana anak muda berada di masa transisi dari sekolah ke kuliah atau dari kuliah ke kerja (Richards and Wilson 2004). Pada kasus ini, backpacking sebagai perjalanan mandiri dianggap memberi ruang edukasi dimana anak muda merencanakan, merancang, mengatur dan mempraktikkan sendiri perjalanannya. Karakteristik tersebut tentu tidak melegitimasi pernyataan bahwa backpacker hanya dilakukan oleh anak muda. Orang dewasa juga backpacker-an meski jumlahnya tidak signifikan.

Dari perspektif historis, praktik perjalanan mandiri sebenarnya sudah ada sejak lama, hanya saja muncul dalam sebutan yang lain. Di Amerika dan Eropa pada abad 18 dan 19 muncul istilah Tramping yang menggambarkan tren orangorang, - biasanya kalangan laki-laki muda kelas bawah- yang meninggalkan rumah dan keluarganya untuk melakukan perjalanan dalam rangka mencari peruntungan dan petualangan (Adler 1985). Pada awal abad 20 muncul sekelompok orang yang melakukan perjalanan meninggalkan kenyamanan untuk hidup dalam nomadisme dan kebebasan yang disebut Hitchhiking (Loker-Murphy and Pearce 1995). Tahun 1960 an, gaya hidup nomaden sebagai bentuk cara hidup alternatif dipraktikkan oleh sekelompok orang yang disebut Drifter (Cohen 1972; O'Reilly 2006). Tahun 60an juga tren fenomena kemunculan kaum Gypsy di Eropa yang hidup mobile tanpa tempat tinggal permanen (Okely 1983).

Menurut Loker-Murphy dan Pearce (1995), istilah backpacker muncul sekitar 1970-an dan menjadi populer, termasuk dalam literatur akademik yang muncul satu dekade kemudian. Memahami siapa itu backpacker dan bagaimana backpacking dilakukan tidak bisa lepas dari keterkaitan historis kelompok orang-orang yang melakukan perjalanan mandiri yang mendahului kemunculannya. Tramp, Hitchiking, Drifter, dan Gypsy tidak hanya menunjukkan rangkaian cara hidup nomaden yang dipraktikkan oleh kebanyakan kaum muda di Barat, tetapi juga perubahan karakteristik yang membentuk karakter kelompok nomaden berikutnya yang lebih kontemporer seperti backpacker.

Adler (1985) mengingatkan kembali bahwa nomadisme kaum muda seperti backpacker sebenarnya bukan fenomena yang baru saja terjadi. Karakteristik dan motif mobilitas Tramping pada pencarian pekerjaan dan kemapanan mempengaruhi kermunculan kelompok traveler muda yang kelasnya lebih bawah dimana perjalanannya diarahkan pada pengalaman dan peruntungan. Menurut Cohen (2003) perkembangan pariwisata massal yang sangat pesat sejak Perang Dunia ke-2 juga berhubungan dengan kemunculan karakteristik traveler yang berorientasi pada kebebasan dan kesenangan, namun tetap memiliki hasrat untuk mengadopsi nomadisme Tramping: Karakter ini pernah diekspresikan secara luas oleh kalangan muda di Amerika dan Eropa, yang melahirkan gerakan revolusioner 1960-an dan berbagai upaya menciptakan cara hidup alternatif, salah satunya adalah Drifter. 
Kaitan antara konteks politik 1960an dengan kemunculan Drifter di Barat membentuk karakteristik nomadisme Drifter awal yang cenderung individualistis, spontanitas dan mandiri. Pada konteks melakukan perjalanan, Drifter pergi tanpa itinerari, tanpa lokasi destinasi yang pasti, dan tanpa mendefinisikan secara konkret apa tujuannya (Cohen 1973). Tentu saja konteks historis yang selalu dinamis membentuk perkembangan Drifter yang bisa jadi berbeda dengan Drifter awal. Menurut Elsrud (2001) ideologi Drifter awal dalam melakukan perjalanan merupakan salah satu 'prototype' yang diadopsi oleh backpacker kontemporer.

\section{SUBKULTUR BACKPACKER}

Backpacker melakukan perjalanan secara independen. Dalam banyak literatur, backpacker diidentifikasi sebagai tipe traveler atau turis yang mengatur perjalanannya sendiri (Sørensen 2003; Cohen 2003; Noy 2004; Welk 2004). Backpacker merencanakan pergi ke suatu tempat yang akan menjadi destinasinya, meskipun dengan itinerari yang fleksibel. O'Reilly (2006) menyebut tipe pejalan seperti itu cenderung menaruh perhatian lebih pada aspek budget. Tidak selalu karena keterbatasan ketersediaan budget, tetapi sikap untuk konsen pada upaya membatasi pengeluaran finansial sebagai bagian dari pembentukan pengalamannya traveling: Mengidentifikasi backpacker dengan menyebutkan berbagai karakteristik tersebut dapat memberi petunjuk untuk mendefinisikan apa itu backpacker, namun belum memberi penjelasan yang objektif terkait apa bedanya dengan kelompok pejalan lain seperti traveler dan turis pada umumnya (Sørensen 2003).

Meskipun backpacker sering dikategorikan sebagai tipe turis, konstruksi identitas yang dibangun oleh backpacker tidak jarang menunjukkan sikap anti-turis. Misalnya, touring dengan preferensi off the beaten track atau ke tempat yang tidak/ belum dikunjungi oleh banyak orang yang dijalani oleh backpacker menunjukkan tendensi bahwa backpacker tidak sama dengan turis kebanyakan (Welk, 2004). Studi etnografi yang dilakukan oleh Sørensen (2003) menunjukkan bahwa backpacker sangat konsen pada makna kultural traveling yang diperoleh dari 'status jalanan'. Status jalanan digunakan oleh backpacker sebagai elemen penting untuk mengukur kriteria backpacker 'ideal', seperti membeli sesuatu di destinasi dengan harga lokal, menjelajahi lokasi yang belum pernah dikunjungi turis, memperpanjang kunjungan secara spontan, melewati daerah berbahaya dan mengenakan pakaian kasual yang kadang terlihat agak lusuh.

Ideologi, identitas dan status yang dikonstruksikan backpacker memposisikan tipe pejalan ini sebagai subkultur yang membedakan kelompok backpacker dengan traveler atau turis lainnya. Subkultur backpacker tak jarang tampil dalam penampilan dan praktik traveling yang kontras dengan para turis, meskipun backpacker sering ditemukan mengunjungi destinasi wisata yang sama untuk tujuan kesenangan atau menghabiskan waktu luang sebagaimana turis lainnya. Upaya mengontraskan diri dengan tipe traveler lainnya menunjukkan backpacker sebagai subkultur nomadisme kaum muda yang muncul di era kontemporer.

Sydner (2011) mengidentifikasi bahwa praktik subkultural tidak terbatas pada diskursus ideologi dan identitas yang membedakan kelompok subkultural dengan yang 'mainstream' atau dengan subkultur lain. Lebih dari itu membuka ruang negosiasi anggota komunitas terhadap peluang karier profesional ke depan. Kelompok subkultural meskipun tak jarang dipersepsikan sebagai bentuk 'penyimpangan' atau 'perlawanan' terhadap yang mainstream, memiliki ruang negosiasi yang membuka kemungkinan transisi dari motif kesenangan ke kerja atau karier yang serius. Komunitas backpacker sebagai subkultur memberi ruang negosiasi karier profesional yang memungkinkan anggotanya memasuki dunia kerja atau membangun karier sembari tetap menjadi bagian dari subkulturnya.

\section{KARIER SUBKULTURAL}

Apa yang disebut sebagai karier subkultural, menurut Sydner (2011) merupakan proses produksi karier profesional oleh subkultur dimana karier tersebut direpresentasikan oleh berbagai profesi yang melampaui namun masih berkaitan dengan 
subkulturnya. Karier subkultural menentukan anggotanya meniti karier profesional dengan tetap menjadi bagian dari kelompok subkulturnya. Studi Sydner (2011) tentang subkultur skateboarding menunjukkan proses produksi peluang karier profesional skating yang melampaui karier sebagai pemain profesional skateboard, seperti fotografer, editor video, seniman, desainer grafis, dan pengusaha skate.

Karier subkultural berkaitan erat dengan munculnya kultur 'do-it-yourself' (DIY) yang dipraktikkan oleh anak-anak muda dalam subkulturnya. Komunitas subkultur adalah ruang ekspresi sekaligus investasi kultur DIY yang menopang kemunculan karier subkultural yang banyak dipraktikkan. Inisiasi kreatif kaum muda berpartisipasi dalam karier subkultural berkontribusi pada kesuksesan memperpanjang partisipasinya dalam subkultur. Terlebih lagi kaum muda yang berada dalam masa transisi menuju dewasa dan transisi dari sekolah atau kuliah menuju kerja. Masa transisi menyiratkan adanya keterbatasan dalam partisipasi subkultur. Adanya karier subkultural memungkinkan eliminasi halangan pembatas partisipasi anak muda di komunitas subkultural.

Karier subkultural tampak potensial menjadi solusi dari problem sosial yang persepsikan lahir dari komunitas subkultural. Becker (1963) melihat partisipasi individu dalam kelompok subkultural membentuk proses belajar yang diorganisir dalam aktivitas yang menyimpang dari yang mainstream. Selain itu, kelompok subkultural cenderung mengekspresikan sikap ketidakpedulian terhadap eksistensi regulasi atau aturan. Ketidakpeldulian ini bisa saja berasal dari ketidaksadaran atau ketidaktahuan individu terhadap adanya proses klasifikasi apa yang pantas dan tidak pantas dalam masyarakat tertentu. Namun ketidakpedulian, ketidaksadaran atau ketidaktahuan muncul di area dimana struktur sosialnya membentuk kondisi tersebut.

Subkultur backpacker dapat dibaca sebagai potret 'penyimpangan' dari 'aturan' traveling mainstream seperti yang dipraktikkan oleh para traveler atau turis pada umumnya. Partisipasi traveler muda dalam karier subkultural backpacker merefleksikan upaya melewati transisi dari sekadar minat ke karier dengan tetap menjadi bagian dari anggota subkultur. Karier backpacker memberikan peluang partisipan untuk tetap engage dalam aktivitas traveling; mempraktikkan mobilitas melampaui kesenangan, dan menggeser orientasi dari traveling untuk tujuan travel itu sendiri menjadi kerja. Karier subkultural backpacker memperlihatkan potensi konvergensi antara kerja dan jalan-jalan seperti yang dipraktikkan backpacker yang merintis usaha sendiri atau membangun karier di dunia travel.

Studi akademik tentang backpacker sebagai sebuah komunitas kultural sudah pernah dilakukan (Sørensen 2003; Adkins and Grant, 2007; Cohen 2011). Namun demikian, kebanyakan studi belum mengeksplorasi potensi karier subkultural yang dipraktikkan oleh backpacker di dunia travel. Padahal, traveling merupakan salah satu aktivitas penting seiring dengan perkembangan dan pertumbuhan industri travel dan pariwisata. Backpacker yang meletakkan traveling di jantung aktivitasnya dikelilingi oleh industri yang memungkinkan backpacking menjadi karier yang dijalani oleh para traveler. Ditambah lagi adanya produk, media, seni dan infrastruktur seperti akomodasi dan transportasi yang berkaitan dengan backpacker dan disediakan untuk memfasilitasi aktivitas backpacking: Studi ini fokus pada produksi karier subkultural backpacker di dunia travel kontemporer.

\section{METODE PENELITIAN}

Studi ini menggunakan pendekatan kualitatif dengan sumber data utama berasal dari wawancara mendalam terhadap anggota komunitas backpacker dan observasi netnografis konten online yang diproduksi backpacker di akun media sosialnya. Studi ini melibatkan 15 backpacker asal Indonesia yang intens traveling ke luar negeri dan memilih merintis usaha atau berkarier di dunia traveling: Wawancara dilakukan pada Maret 2017 baik secara tatap muka ataupun online. Wawancara tatap muka dilakukan di dua kota yaitu Bandung dan Yogyakarta, lokasi dimana komunitas backpacker aktif melakukan kopdar. Wawancara online diselenggarakan dengan medium yang mendukung synchronous communi 
cation (Rettie 2009) seperti videocall dan voicecall supaya potensi distorsi makna hasil wawancara dapat diminimalisir. Observasi online diterapkan dengan cara mengamati, merekam dan menganalisis konten media sosial informan yang berkaitan kegiatan traveling yang dilakukannya.

Mengikuti postingan yang dipublikasi oleh informan di media sosial menjadi bagian penting dalam proses pengumpulan data riset ini. Traveler atau backpacker memiliki mobilitas yang tinggi sehingga menemuinya merupakan tantangan bagi peneliti (Sørensen 2003). Namun dalam mobilitas itu, traveler sering kali sharing informasi atau opini tentang pengalaman perjalanannya lewat akun media sosialnya. Aktivitas online telah menjadi bagian integral dari kelompok kultural kontemporer seperti backpacker sehingga media online menjadi sumber data penting yang dapat dimanfaatkan peneliti (Kozinets 2010). Subjek penelitian ini merupakan anggota komunitas backpacker yang sering berinteraksi secara online, sehingga konten onlinenya dapat dianalisis untuk membantu memahami aktivitas dan pengalaman traveling yang dilakukannya.

Data yang dikumpulkan untuk proses analisis setidaknya mengandung tiga narasi berikut: pengalaman dan motivasi traveling, pilihan karier atau usaha di dunia travel, dan makna traveling: Peneliti memulai pengumpulan data dengan melakukan entry pada komunitas backpacker Indonesia. Bergabung dengan komunitas backpacker memberi kesempatan pada peneliti untuk engage dengan para traveler yang memiliki minat pada backpacking. Peneliti menyeleksi secara random partisipan berdasarkan relevansi konten yang diproduksi dengan pertanyaan riset ketika masa observasi online. Selanjutnya, peneliti menginisiasi wawancara. Proses wawancara dimulai dengan sharing pengalaman traveling yang pernah dilakukan oleh informan. Memulai interview dengan sharing pengalaman memberi peluang pada partisipan untuk bersikap lebih terbuka selama proses wawancara. Selain itu, partisipan juga memulai proses interview dengan kesan lebih antusias. Interview guide yang tersusun atas pertanyaan terbuka, membuat informan lebih bebas bercerita.

Peneliti mengamati aktivitas online di komu- nitas tersebut secara intensif. Konten online yang diproduksi oleh partisipan yang relevan dengan masalah penelitian dilibatkan sebagai data penelitian. Meskipun konten online tersebut dapat diakses oleh seluruh anggota komunitas, partisipan belum tentu berekspektasi bahwa konten yang diposting di forum akan di-reshare di tempat lain, termasuk di laporan penelitian. Untuk mengatasi problem etis ini, peneliti tidak menggunakan nama asli informan serta manyamarkan nama akun informan yang kontennya dilibatkan sebagai data lapangan.

Data wawancara kemudian ditranskrip secara verbatim. Sedangkan data hasil pengamatan konten online dikumpulkan dengan teknik screensaving: Kedua jenis data tersebut dikompilasi untuk proses analisis. Dalam proses koding, peneliti menggunakan teori karier subkultural dan identitas backpacker untuk mengonstruksikan tema berbasis pada data tekstual di lapangan. Teknik ini menerapkan proses simultan antara induktif dan deduktif, dimana tema yang diangkat berbasis pada data lapangan, namun teori tetap berperan sebagai "panduan" dalam mengonstruksi narasi tematik terkait aktivitas backpacking sebagai potensi karier subkultural yang dinarasikan oleh informan.

\section{RAGAM KARIER BACKPACKER}

Pengalaman traveling merupakan salah satu insentif paling berharga yang diperoleh setiap pelancong termasuk turis backpacker. Perjalanan mandiri yang dipraktikkan backpacker memungkinkan dirinya mendapat pengetahuan detail tentang proses traveling dari sebelum pergi, di destinasi, sampai kembali, ketimbang turis berkelompok yang setiap langkah perjalanannya sudah diatur oleh agen atau biro travel. Karakteristik backpacker yang independen menjadi modal krusial dalam proses akumulasi pengalaman dan pengetahuan yang dianggap lebih mengakar, mendalam dan tak terlupakan karena backpacker merancang, mempraktikkan dan mengatur sendiri mobilitas perjalanannya. Backpacker mampu mengulangi perjalanannya dengan mudah karena memperoleh informasi teknis yang lengkap dari pengalaman perjalanan yang dilakukan sebelumnya. 
Akumulasi pengetahuan dan pengalaman backpacker berlangsung selama proses traveling itu sendiri. Traveling bagi backpacker memberi kesempatan untuk mengekstrak pelajaran yang tidak mungkin diperoleh dengan ikut biro perjalanan, apalagi dengan diam di rumah. Salah satu informan memaparkan alasannya backpacking.

"Lebih ke pelajarannya sih, bukan kayak oh selfienya gitu dengan ngunjungi tempat-tempat turisnya. Jadi lebih ke pelajaran, salah satunya kayak gitu, ketemu orang kita belajar untuk lebih open-minded, belajar lifestyle-nya mereka, kadang aku traveling mau kemana, ngga tau di situ ada apa itu nggak tau" (Rama, laki-laki 25 tahun).

Backpacker tak jarang tidak dilengkapi atau tidak mau melengkapi dirinya dengan informasi detail tentang destinasi. Namun keberadaannya di destinasi memberi kesempatan untuk memperoleh informasi dan pengetahuan tentang kultur yang berbeda. Paparan terhadap perbedaan kultur seperti gaya hidup orang-orang di destinasi merupakan materi yang membantunya belajar tentang bagaimana berpikir dan bersikap lebih terbuka. Pelajaran yang diperoleh backpacker tidak hanya berasal dari paparan perbedaan kultur di destinasi, namun juga interaksi dan koneksi yang dibangun dengan orang lain. Independensi backpacker menuntut dirinya untuk mempraktikkan apa yang disebut sebagai 'seni berjejaring'.

"Backpacker itu kan kita harus saling berkomunikasi. Kenalan itu tidak mencari secara random, tapi di komunitas backpacker kita nanya 'eh kamu punya kenalan ngga di negara ini?' 'oh ya punya', 'boleh dong dikasih Whatsapp-nya', baru kemudian kita cari Facebook atau Instagram-nya untuk meyakinkan bahwa oh ini orang bisa dipercaya, ngga macem-macem seperti gitu, karena kan siapa tau kalo kita salah orang, mungkin di sana kita dimanfaatkan atau di sana malah kita di-scam" (Frizky, laki-laki 27 tahun).

Relasi sosial yang dibangun oleh sesama backpacker merupakan elemen penting yang membentuk karakteristik perjalanan backpacker. Jejaring yang dibangun sebelum perjalanan biasanya dimulai dengan snowballing dari kenalan di komunitas backpacker. Tidak hanya dalam konteks pra-perjalanan, membangun relasi melalui pertukaran informasi juga sering kali dipraktikkan backpacker ketika bertemu di destinasi. Murphy (2008) mengatakan bahwa berinteraksi dengan sesama traveler lain memberi arti penting bagi pembentukan pengalaman perjalanan backpacker. Di destinasi, backpacker bertemu dengan backpacker lain untuk bertukar informasi yang sama-sama dibutuhkan, misalnya tentang ongkos ke suatu destinasi, tempat makan, sapaan lokal, kultur lokal, resiko dan sebagainya, termasuk identitas mereka sebagai backpacker itu sendiri. Informasi tersebut sangat penting bagi perjalanan backpacker sehingga interaksi sosial menjadi komposisi krusial dalam praktik perjalanan backpacker.

Informasi, pengetahuan dan pelajaran yang diperoleh dari praktik traveling tidak hanya menjadi pengalaman yang selalu berhenti pada memori atau catatan saja, tetapi juga modal penting dalam menginisiasi peluang karier backpacker yang hobi traveling. Pengalaman backpacking sebagai modal karier backpacker terefleksikan dari munculnya beragam model usaha perjalanan yang kebanyakan diinisiasi oleh backpacker yang berpengalaman dan menjadi karier atau usaha yang dirintis oleh backpacker itu sendiri. Beberapa model perjalanan backpacker yang ditemukan dalam penelitian ini diklasifikasi menjadi tiga, yaitu open trip, sponsored trip dan business trip.

\section{a. Open Trip}

Pengalaman backpacker memesan tiket, merancang itenerari, menentukan destinasi, memilih tempat menginap, makan, berfoto dan seterusnya menjadi modal penting untuk melakukan open trip. Open trip merupakan istilah yang menjelaskan model perjalanan dimana traveler - biasanya individual, untuk membedakan dengan biro perjalanan yang organisasional - yang menyelenggarakan open trip sudah menentukan daftar spot kunjungan di destinasi lengkap dengan kebutuhan dan biayanya. Tiketing; transportasi, akomodasi dan kebutuhan lainnya sudah ditentukan di awal dengan perhitungan ongkos yang detail. Penyelenggara open trip kemudian 
memposisikan rencana detail perjalanannya itu sebagai 'paket perjalanan' yang ditawarkan secara terbuka (open) kepada siapapun yang berminat.

Paket perjalanan tersebut pada umumnya lebih murah ketimbang paket perjalanan yang ditawarkan oleh penyelenggara perjalanan resmi seperti agen travel. Harga paket cenderung lebih murah karena backpacker yang menyelenggarakan open trip mengalkulasi estimasi biaya berbasis pengalamannya dan pengetahuannya menakar harga lokal. Pertimbangan pada 'harga lokal' membentuk karakteristik tipe perjalanan open trip yang umumnya -meskipun tidak selalu lebih murah dibanding biro perjalanan resmi. Dengan model seperti itu, penyelenggara open trip berperan layaknya biro perjalanan, namun dengan beberapa perbedaan karakteristik. Salah satu informan penyelenggara open trip menceritakan pengalamannya sebagai berikut:

"Banyak yang mengirimkan pesan berisi keinginan untuk backpacking bersama saya which is I don't know why. But well, karena saya tidak ada kerjaan dan saya sendiri sedang kebingungan untuk membiayai trip selanjutnya, so saya berpikir kenapa ngga dicoba, saya bisa menolong orang dan saya pun bisa traveling gratis. Akhirnya sayapun menawarkan open trip actual cost, artinya saya tidak mengambil keuntungan, dengan pendampingan gratis dan secara mengejutkan banyak yang berminat. Dan di bulan yang sama secara mengejutkan juga saya ditawari untuk berkeliling Jawa-Bali-Lombok-Sumbawa-Flores gratis. Jadi dari saya yang sama sekali tidak ada kerjaan menjadi saya yang super sibuk. Sibuk traveling dan sibuk arrange trip" (Lia, perempuan 30 tahun).

Backpacker penyelenggara open trip sangat bergantung pada pengalamannya traveling yang pernah dilakukan sebelumnya. Open trip sendiri memiliki beberapa varian. Misalnya actual cost dan share cost. Share cost menekankan adanya biaya total perjalanan yang di-share merata pada seluruh peserta open trip (Wiweka dkk, 2019). Tipe actual cost seperti yang diceritakan oleh informan menekankan pada biaya aktual yang dibankan kepada peserta open trip. Keduanya menjadi basis lebih rendahnya biaya perjalanan tipe open trip ketimbang traveling melalui biro resmi.

Inisiator open trip berperan sebagai pemandu perjalanan dengan insentif yang kadang nonfinansial. Jalan-jalan gratis merupakan salah satu insentif yang diterima insiator open trip dari peserta open trip. Meskipun mungkin tidak mendapatkan keuntungan finansial, backpacker penyelenggara open trip telah menginfiltrasi unsur kerja dalam traveling-nya dimana ia menyusun rencana perjalanannya, memandu dan mendampingi peserta selama perjalanan, hingga kembali ke destinasi.

\section{b. Endorsed Trip}

Pengalaman backpacker yang diperoleh dari perjalanan sebelumnya menjadi modal untuk mereduksi biaya traveling berikutnya. Bahkan reduksi biaya berpotensi sampai angka nol dimana kebutuhan finansial perjalanan backpacker didukung atau ditopang oleh pihak lain. Tipe perjalanan backpacker ini muncul pada perjalanan yang disebut endorsed trip. Endorsed trip merupakan tipe perjalanan dimana traveler melakukan perjalanan dengan support finansial baik sebagian ataupun keseluruhan dari pihak lain. Pihak lain tersebut adalah pemberi endorse atau sponsor. Jika dukungan finansialnya menyeluruh, maka traveler tidak menanggung biaya apapun untuk traveling. Model perjalanan endorsed trip diceritakan oleh informan sebagai berikut:

"Kalo saya, kalo mau ngetrip cari duit juga, cari endorsan. Saya udah endorsan nih buat bulan depan ke Turki, kan lumayan, kalo misalnya tambahan buat beli-beli bagasi ya lumayan lah dapet. Jadi kan kalo punya produk apa gitu, saya tawarin. Kalo punya produk yang mau difoto di sana gitu. Kalo yang kemarin dapet bakpia, dapet gudeg, trus dapet rendang. Dibawain itu, yaudah kita foto di sana, kan bagi pemilik produknya kalo mereka buat iklan kan itu seolah-olah udah go international' (Lani, perempuan 29 tahun).

Reduksi biaya perjalanan merupakan elemen penting bagi backpacker yang konsen pada aspek budget. Endorsed trip dipersiapkan matang oleh backpacker dengan menawarkan jasa iklan pada perusahaan atau industri yang minat memasarkan prod- 
duknya. Pengalaman informan menunjukkan bahwa endorsed trip lebih mudah direalisasikan pada perjalanan ke luar negeri karena aspek go internasional menjadi suatu bentuk 'kontra prestasi' yang sangat dipertimbangkan oleh pemberi sponsor.

Upaya mencari endorsan atau sponsor menunjukkan adanya integrasi aspek kerja pada kegiatan pra-traveling dan ketika di destinasi. Tipe ini menuntut backpacker untuk berperan layaknya talenta iklan komersial yang bersedia memasarkan produk di tengah perjalanannya. Dengan sendirinya, traveling yang dilakukannya menjadi perjalanan komersial. Berada di destinasi, memotret produk dengan background ikon wisata di luar negeri dalam rangka memasarkan produk merupakan aktivitas kerja backpacker yang berangkat melakukan perjalanan dengan model endorsed trip.

\section{c. Bussiness Trip}

Model business trip disini tidak terbatas pada definisi perjalanan bisnis dimana traveler melakukan mobilitas untuk keperluan bisnis, terutama untuk perjalanan yang dilakukan pertama kali. Business trip merujuk pada potensi kerja profesional di dunia travel yang diinisiasi dan dikembangkan melalui pengalamannya backpacking. Beberapa pekerjaan yang dipraktikkan dengan model perjalanan ini diantaranya usaha tur dan travel, tour guide profesional, dan jasa penitipan atau dikenal dengan istilah jastip. Business trip bagi backpacker menekankan pada pengembangan usaha berorientasi profit yang diinisiasi melalui traveling. Traveling juga merupakan bagian dari cara mengembangkan bisnis di bidang travel. Dengan model ini, traveling tidak lagi sekadar aktivitas hobi tetapi juga aktivitas kerja dan karier. Mobilitas traveling bagi backpacker berpotensi menjadi permanen karena traveling merupakan salah satu moda produksi penting yang gunakan untuk mengembangkan usahanya. Dalam praktik pengembangan usaha, backpacker memperlakukan traveling melampaui aktivitas yang sekadar jalanjalan.

"Jadi bukan hanya sekadar jalan-jalan biasa. Tapi di situ kita jadi cari kenalan, siapa tau kenalan hari ini adalah relasi bisnis, partner bisnis di masa yang akan datang. Jadi intinya dengan siapapun kita harus bermitra, berpartner" (Fredy, laki-laki 27 tahun).

Backpacking merupakan bagian dari upaya mengembangkan usaha. Pada kasus ini, traveling menjadi aktivitas krusial dalam membangun jejaring. Tipe perjalanan backpacker sangat identik dengan bertemu dan berinteraksi dengan orang-orang asing di destinasi asing. Bertemu orang baru tak jarang menjadi motivasi perjalanan backpacker. Oleh sebab itu, traveling merupakan bagian dari upaya memanfaatkan sumber daya yang menguntungkan usaha yang dikembangkannya.

Tidak hanya membangun relasi dan berjejaring. Traveling juga menjadi medium pengembangan usaha yang ditekuni traveler. Sebagai contoh, salah satu informan membangun usaha produk jilbab yang dimulai dengan aktivitas backpacking ke Turki. Usaha yang dikembangkannya memberi kesempatan untuk melakukan perjalanan pulang-pergi ke Turki untuk membeli barang dan dijual di tempat asalnya. Inisiasi usahanya diceritakan dalam narasi berikut.

"Idenya itu dari waktu saya backpackeran ke Turki, shopping di Grand Bazaar, liat kerudung itu cantik-cantik, akhirnya saya bawalah. Belilah beberapa, bawa ke Indonesia ternyata bagus. Dari segi bahan, motif akhirnya saya cari relasi dimana grosirnya. Itu kan April saya berangkat, sebulan kemudian saya berangkat lagi untuk sengaja mengambil kerudung. Jadi memang mengkhususkan diri untuk ngambil kerudung. Awalnya ke Turki jalan-jalan karena ada tiket promo 4 juta rupiah pulang-pergi dari Johor Kuala Lumpur, Malaysia Airline. Johor-KL-Doha-Istanbul. Pulangnya pun sama demikian. Sangat murah sekali waktu itu dapet tiket dari sini ke Johor baru itu sekitar 700 ribu rupiah pulang-pergi" (Frizky, laki-laki 27 tahun).

Backpacker yang mentransformasi perjalanannya dari minat subkultural menjadi kulakan memiliki kesempatan untuk memperpanjang mobilitasnya. Menginisiasi usaha dari pengalamannya traveling dilakukan informan dengan mempertimbangkan beberapa aspek, salah satunya harga tiket maskapai. 
Meskipun model ini mirip seperti bekerja sebagai pedagang konvensional dimana pengusaha mengambil untung dari selisih harga beli dan jual, usahanya tidak dapat diinisiasi tanpa praktik backpacking yang membuka peluang traveler berbisnis. Usaha yang dirintis memberi peluang informan untuk memperpanjang nomadisme-nya kerena tuntutan mengembangkan usaha melalui pengulangan perjalanan.

\section{BACKPAKING SEBAGAI KARIER SUBKUL- TURAL}

Open trip, sponsored trip dan business trip yang diinisiasi dan dipraktikkan oleh backpacker merefleksikan munculnya tren peluang karier subkultural di komunitas traveler. Backpacker yang menginisiasi tipe perjalanan tersebut berpartisipasi dalam karier subkultural, terutama di dunia traveling. Pengalaman backpacker dalam melakukan perjalanan, mengunjungi destinasi dan membangun jejaring untuk kepentingan traveling menjadi modal penting dalam meniti karier dan usaha di dunia travel. Open trip adalah model perjalanan setipe dengan desain paket wisata yang sebelumnya banyak dipraktikkan oleh agen atau biro travel. Kini backpacker secara individual mampu mendesain sendiri paket perjalanannya dengan menawarkan share cost atau actual cost. Karakteristik perjalanan backpacker dengan itinerari yang sering kali fleksible mempengaruhi munculnya dua cara membiayaan perjalanan tersebut. Fleksibilitas perjalanan mempengaruhi besaran biaya paket yang ditawarkan yang tidak dapat diprediksi. Lewat media sosial, informan menawarkan paket open trip dengan menyebut biaya yang tidak murah sekaligus tidak dapat diprediksi.

"Jadi, kalau kamu cari paket tur yang enak dan murah meriah, disini bukan tempatnya. Saya punya beberapa teman yang menawarkan paket tour dengan harga terjangkau, saya bisa merekomendasikan mereka. Sedangkan perjalanan yang akan didapatkan di sini adalah kotak tertutup yang saya sendiri tidak tahu apa isinya, apakah salah turun stasiun, apakah ngampar di terminal, apakah nyasar, apakah kedinginan di border, apakah perjalanan cross border yang me- makan waktu sampai berpuluh-puluh jam, saya tidak tau. Saya menawarkan pengalaman backpacking yang kadang jauh dari kenyamanan, tetapi percayalah, tidak akan menyesal" (Lia, perempuan 30 tahun).

Deskripsinya mengenai open trip yang diinisiasi menunjukkan karakteristik yang kontras dengan paket tur yang ditawarkan oleh biro travel. Ketimbang mempromosikan dengan label murah, backpacker menyebut paket perjalannnya sebagai 'kotak tertutup'. Ketimbang menawarkan perjalanan yang nyaman, backpacker menawarkan kejutan yang bisa datang dari kondisi yang tidak dapat diprediksi atau resiko dari perjalanan itu sendiri seperti nyasar, tidur di jalan, dan sebagainya. Di sini, terlihat karakteristik open trip yang diinisiasi oleh backpacker berbeda dengan paket tour yang sudah mapan sebelumnya. Open tour backpacker dipengaruhi oleh karakteristik perjalanan backpacker itu sendiri yang cenderung fleksible, tidak dapat diprediksi dan konsen pada budget.

Inisiasi backpacker menyelenggarakan open trip, sponsored trip dan business trip, menunjukkan potensi karier subkultural bagi kalangan backpacker. Paritisipasi backpacker dalam karier subkulturalnya, menggambarkan suatu perpanjangan mobilitas backpacker yang semula sekadar minat atau hobi menjadi kerja yang menguntungkan. Backpacker memperoleh keuntungan dari pekerjaannya dalam bentuk open tour, sponsored trip atau business trip, meskipun keuntungan yang diperoleh tidak selalu dalam bentuk finansial. Traveling itu sendiri bagi backpacker bisa menjadi suatu bentuk insentif yang menguntungkan sebab backpacker dituntut untuk selalu dalam keadaan mobile. Tentu saja backpacker tinggal sementara di destinasi atau pada akhirnya memilih menetap atau pulang ke rumah, namun tanpa mobilitas dari suatu tempat ke tempat lain, backpakcing akan hilang maknanya.

Karier subkultural backpacker menunjukkan adanya peran krusial mobilitas dalam aktivitas kerja. Hal ini karena subkultur backpacker memiliki satu aktivitas yang tidak bisa digantikan, yaitu mobilitas fisik mengunjungi suatu tempat ke tempat lain. Nomadisme backpacker adalah nyawa dari identitas backpacker itu sendiri. Dalam studinya tentang 
karier subkultural skateboarding; Snyder (2011) menemukan bahwa karier subkultural dibangun dari kebutuhan untuk mendokumentasikan dan mendiseminasikan trik bermain skateboard, media publikasi tentang skateboard, produk-produk skateboard yang membentuk skating sebagai industri yang memunculkan peluang karier subkultural. Berbeda dengan skating, fondasi karier subkultural backpacker dibangun dari kebutuhan akan mobilitas yang secara intens dipraktikkan oleh backpacker itu sendiri.

Mobilitas bagi backpacker tidak sekadar aktivitas fisik mengunjungi destinasi, tetapi juga mengandung makna kultural yang tidak bisa diperoleh tanpa mobilitas. Dengan kata lain, mobilitas adalah salah satu moda produksi yang tak tergantikan. Makna kultural mobilitas membentang sekaligus mengakar kuat dalam motivasi traveling yang dibangun oleh backpacker. Ketika ditanya tentang makna traveling, informan berulang-ulang menyebut istilah life-changing experience sebagai kompensasi yang diperoleh dari pengalamannya backpacking. Makna itu juga dikonfirmasi dalam postingannya di media sosial ketika berbagi tips tentang traveling:

"Travelling itu bukan ngabisin uang, itu investasi kok buat personal growth! Travelling itu juga bukan sekedar foto-foto doang, kamu harus ketemu orang baru, belajar budaya mereka, dan yang paling penting kalo bisa dapet life-changing experience dari setiap trip kamu" (Rama, laki-laki 25 tahun).

Pengalaman yang mengubah hidup menjadi semacam produk yang dibeli dengan uang yang dihabiskan untuk traveling. Di tengah munculnya tren anak-anak muda yang lebih memilih mengonsumsi pengalaman ketimbang produk, traveling menjadi salah satu segmen yang diminati kalangan muda. Pengalaman backpacking tidak hanya diharapkan dapat mengubah hidup mereka yang backpacker-an, tetapi juga diharapkan memberi dampak pada perubahan sosial yang lebih luas. Salah satu informan meletakkan ekspektasi pada perubahan sosial melalui aktivitas backpacking yang dipraktikkan oleh anak-anak muda.

"Saya menginisiasi, meng-encourage orang-orang un- untuk pergi, terutama yang muda-muda, karena untuk melihat yaitu di luar kayak gimana, bisa diaplikasikan apa ngga ke kita, ke kehidupan sosial kita. Terutama kan kalo anak muda itu kan yang jadi agent of change, jd berharap ya ada perubahan-perubahan, atau minimal perubahan perilakulah" (Santi, perempuan 31 tahun).

Pengalaman yang mengubah hidup tidak dapat diperoleh tanpa pergi melakukan perjalanan. Namun pengalaman tersebut baru bernilai ketika kembali pulang dimana terjadi perubahan pada diri traveler atau inisiasi oleh traveler untuk berkontribusi pada masyarakat sekitar melalui perannya sebagai agen perubahan. Nomadisme backpacker dengan pergi dan pulang menunjukkan peran mobilitas sebagai aktivitas tak tergantikan bagi karier subkultural backpacker.

\section{KESIMPULAN}

Backpacker meletakkan traveling di jantung aktivitasnya sehingga mobilitas menjadi elemen tak tergantikan, tidak hanya untuk pembentukan identitas backapacker, melainkan juga preferensi backpacker dalam membangun karier di dunia travel kontemporer. Tiga model perjalanan backpacker yaitu open trip, endorsed trip, dan business trip yang diinisiasi oleh backpacker menunjukkan potensi backpacking sebagai karier subkultural di dunia travel kontemporer. Pengalaman backpacker tidak bisa dipisahkan dari mobilitas yang dipraktikkannya, sehingga partisipasi dalam karier subkultural memperihatkan integrasi antara kerja dan traveling.

Identitas backacker sebagai pejalan mandiri dengan karakteristik perjalanan yang cenderung fleksibel, menaruh perhatian pada budget, dan resiko tak terduga sebagai komposisi pengalaman, mempengaruhi paket perjalanan yang ditawarkan dan usaha travel yang dikembangkan. Model open trip ditawarkan sebagai kotak tertutup dimana kondisi di destinasi yang tidak dapat diprediksi menjadi bagian dari paket yang ditawarkan. Model endorsed trip memperlihatkan upaya backpacker menawarkan dirinya sebagai talent pengiklan produk usaha sebelum berangkat traveling: Model 
business trip menunjukkan insiasi buka usaha yang berlanjut pada pengulangan perjalanan ke destinasi dalam rangka mengembangkan usaha.

Ketiga model perjalanan tersebut memberi peluang pada aktivitas backpacking untuk menjadi karier subkultural dimana mobilitas backpacker menjadi permanen karena kebutuhan untuk mempertahankan dan mengembangkan kariernya. Mobilitas permanen merupakan hasil dari perpanjangan perjalanan subkultur backpacker yang semula lebih banyak dilakukan sebagai bagian dari situs peralihan dari minat menjadi kerja, dari hobi menjadi karier subkultural. Integrasi kerja dalam aktivitas jalanjalan yang diekspresikan dalam praktik open trip, endorsed trip dan business trip memperkuat potensi backpacking sebagai karier subkultural di dunia travel kontemporer.

\section{DAFTAR PUSTAKA}

Adkins, Barbara and Eryn Grant. 2007. "Backpackers as a Community of Strangers: The Interaction Order of an Online Backpacker Notice Board." Qualitative Sociology Review 3(2):188-201.

Adler, Judith. 1985. "Youth on the Road: Reflections on the History of Tramping." Annals of Tourism Research 12: 335-354

Becker, Howard S. 1963. Outsiders: Studies in the Sociology of Diviance. London: The Free Press.

Cohen, Erik. 1972. "Toward a Sociology of International Tourism." Social Research 39(1):164-82.

Cohen, Erik. 1973. "Nomads from Affluence- Notes on the Phenomenon of Drifter-Tourism1." International Journal of Comparative Sociology 14:1-2.

Cohen, Erik. 2003. "Backpacking: Diversity and Change." Journal of Tourism and Cultural Change 1(2):95-110.

Cohen, Scott A. 2011. "Lifestyle Travellers: Backpacking as a Way of Life." Annals of Tourism Research 38(4): 1535-1555.

Elsrud, Torun. 2001. "Risk Creation in Traveling: Backpacker Adventure Narration." Annals of
Tourism Research. 28/3): 597-617.

Kozinets, Robert V. 2010. Netnography: Doing Ethnographic Research Online. London: Sage Publications.

Loker-Murphy, Laurie and Philip L. Pearce. 1995. "Young Budget Travelers: Backpackers in Australia." Annals of Tourism Research 22(4): 819-843.

Murphy, Laurie. 2008. "Exploring Social Interactions of Backpackers." Annals of Tourism Research 28(1):50-67.

Noy, Chaim. 2004. "This Trip Really Changed Me: Backpackers' Narratives of Self-Change." Annals of Tourism Research 31(1): 78-102.

O’Reilly, Camille Caprioglio. 2006. "From Drifter to Gap Year Tourist. Mainstreaming Backpacker Travel." Annals of Tourism Research 33(4): 998-1017.

Okely, Judith. 1983. The Traveller Gypsies. Cambridge: Cambridge University Press.

Rettie, Ruth. 2009. "Mobile Phone Communication: Extending Goffman to Mediated Interaction." Sociology 43(3):421438.

Richards, Greg. 2015. "The New Global Nomads: Youth Travel in a Globalizing World." Tourism Recreation Research 40(3): 340-352.

Richards, Greg and Julie Wilson, eds. 2004. The Global Nomad: Backpacker Travel in Theory and Practice. Clevedon: Channel View Publications.

Snyder, Gregory J. 2011. "The City and the Subculture Career: Professional Street Skateboarding in LA." Ethnography 13(3):306-29.

Sørensen, Anders. 2003. "Backpacker Ethnography." Annals of Tourism Research 30(4):847-67.

Wiweka, Kadek, Suci Sandi Wachyuni, Sinta Prasintya Simawang, Pramania Adnyana, and Eka Wihartaty. 2019. "Current Issues of Backpacking Tourism Development: Profile and Characteristics of 'Sharecost' and 'Opentrip' Tourist." Journal of Education, Society and Behavioural Science 30(2):1-12. 
